\title{
Reproductive Determinants of Breast Cancer in Women in Indonesia
}

\author{
Sukmayenti Sukma ${ }^{1,2 *}$, Nursyirwan Effendi ${ }^{3}$, Wirsma Arif Harahap ${ }^{4}$, Hardisman Dasman ${ }^{5}$ \\ ${ }^{1}$ Department of Public Health Science, Doctoral Program, Faculty of Medicine, Andalas University, Padang, West Sumatera, \\ Indonesia; ${ }^{2}$ Department of Midwifery, Faculty of Vocational, Baiturrahmah University, Padang, West Sumatera, Indonesia; \\ ${ }^{3}$ Department of Social and Political Science, Faculty of Social and Political Science, Andalas University, Padang, West \\ Sumatera, Indonesia; ${ }^{4}$ Department of Surgery, Division of Surgical Oncology, Faculty of Medicine, Andalas University, Padang, \\ West Sumatera, Indonesia; ${ }^{5}$ Department of Public Health and Community Medicine, Faculty of Medicine, Andalas University, \\ Padang, West Sumatera, Indonesia
}

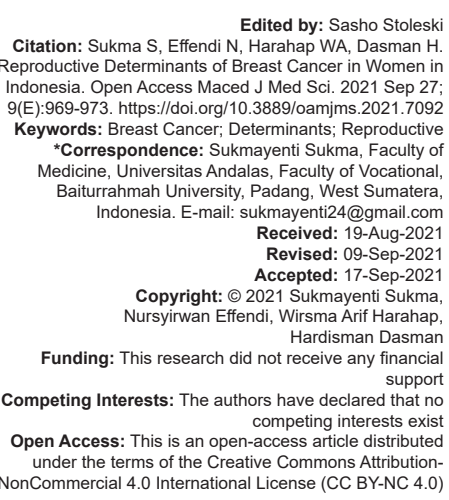

\section{Introduction}

The number of breast cancer cases has increased significantly every year, so that breast cancer is a major health problem both in the world and in Indonesia. Breast cancer is a non-communicable disease, mainly affecting women. In the female population of the world, the incidence of breast cancer ranks first for the number of new cases $(43.3 \%)$ and the number of deaths (15\%) [1]. Each year, breast cancer kills more than 500,000 women worldwide [2]. Judging from the trends in breast cancer cases in Asian countries, it is known that the Philippines is the country with the highest cases compared to Thailand, Singapore, China, India, and Japan [3].

The estimated incidence of breast cancer in Indonesia is 100/100,000 women [2]. This figure increased from the previous year, which was 40/100,000 women
(Riskesdas, 2013). According to the hospital information system, the highest type of cancer in hospitalized patients in hospitals throughout Indonesia in 2010 was breast cancer $(28.7 \%)$, followed by cervical cancer $(12.8 \%)$. At Dharmais Cancer Hospital Jakarta, breast cancer ranks first in the past 10 years to 2016. There has even been an increase in the number of cases each year, where the proportion of breast cancer is around $40 \%$ of the number of other cancer cases in the hospital [4].

The specific cause of breast cancer is still not known with certainty, but many factors are thought to influence the development of breast cancer which is called risk factors. Any risk of breast cancer in women can have a higher or lower probability, depending on several factors which include: Reproductive factors (age of menarche, giving birth to their first child at an advanced age, low parity or childlessness, short, or no lactation period). Ever breastfeeding, and the age of menopause, endocrine factors (oral contraceptives and 
hormone replacement therapy), diet/lifestyle factors (obesity, unhealthy diet, alcohol consumption, smoking, physical inactivity, and stress), and genetic factors (family members with breast cancer, and family history of ovarian cancer) [5].

All women will go through the reproductive process, such as menstruation, pregnancy, childbirth, and breastfeeding. All these reproductive processes are factors that can affect the incidence of breast cancer, where the first menstruation (menarche) at an early age causes the body's exposure to the hormone estrogen to be faster. Pregnancy at an age that is too old $>30$ years causes the period between the age of menarche and the first gestational age to occur hormone discontinuity and breast tissue is very sensitive to this as protection against breast cancer. Meanwhile, slow menopause (>55 years) causes estrogen to remain high in a woman's body so that she is at risk of developing breast cancer

Breast cancer has a broad impact on sufferers both in bio, social and spiritual aspects, as well as on the quality of life of sufferers [6], [7]. Besides, with the increasing number of breast cancer sufferers in a country, it will also increase state spending in terms of breast cancer treatment which is expensive. Therefore, it is necessary to know the risk factors for breast cancer in women so that prevention efforts can be made.

This study aims to determine the risk factors for breast cancer in women in Indonesia, especially in the city of Padang. Risk factors are seen in terms of female reproductive factors such as menarche, age at first birth, parity, breastfeeding, and age at menopause.

\section{Methods}

This study used a case-control study design with a retrospective approach conducted in several hospitals in Padang City, West Sumatra Province, Indonesia (Dr. M. Djamil Hospital and Ibnu Sina Hospital). The case sample was women with breast cancer, while the control sample was women who did not have breast cancer.

The sample size in this study was obtained using the sample formula for a paired case-control study design, with a ratio of 1: 1 . Based on the formula, the total sample size was 77 people and was fulfilled to 100 people so that the total sample amounted to 200 people. The case sample was taken by accidental sampling, while the control sample was using the purposive sampling method.

Before conducting research, first arrange a research permit at the hospital where the research is carried out by bringing a letter from the head of the Public Health Doctoral Study Program, Faculty of Medicine, Andalas University, who previously also received ethical approval from the Ethics Committee of the Faculty of Medicine, Andalas University, Padang. The sample is also asked for consent for willingness to become a sample (informed consent).

This research is a quantitative study using a research questionnaire instrument. Data collection was carried out directly from respondents with a research questionnaire containing questions about women's characteristics such as latest education, occupation, marital status, previous history of cancer, and previous history of breast disease), and contains questions on aspects of reproductive history such as age menarche, age at first birth, total parity, and history of breastfeeding that were previously categorized as risky and non-risky.

Before the research began, the research team who served as enumerators was given training on how to collect data on the sample. Filling out the questionnaire was carried out by the data collector who was carried out in the waiting room of the surgical clinic with direct questions and answers with the sample. Completing this questionnaire takes about 10 min per sample.

The data were collected, coded, and then entered into a computer program using the Statistical Package for the Social Sciences database for Windows version 21. The univariate (descriptive) analysis included frequency and percentage. Bivariate analysis was determined using the Chi-square test including $\mathrm{p}$-value, OR, and $\mathrm{Cl}$ values. The level of significance was set at $p<0.05$. Meanwhile, multivariate analysis was carried out by logistic regression to analyze the relationship of several independent variables with a dichotomous/binary categorical dependent variable which could describe the relationship between the independent variable and the dependent variable in finding the most significant risk factors for predicting the incidence of breast cancer in women.

\section{Results}

Characteristics of respondents are shown in Table 1, where the characteristics of respondents based on the latest education level are still elementary school graduates as much as $6 \%$ in cases, and $7 \%$ in controls. Job-based characteristics were more unemployed in cases $(66 \%)$ than in controls $(55 \%)$. More characteristics based on marital status were married and still had a partner in cases (93\%) than controls (79\%). Characteristics based on a history of the previous cancer were $2 \%$ in controls while in no cases (0). Characteristics based on a history of breast disease previously suffered in $6 \%$ of cases and $7 \%$ of controls.

The results of the univariate analysis are shown in Table 2 that the age distribution of menarche 
Table 1: Frequency distribution of respondents based on characteristics

\begin{tabular}{|c|c|c|c|c|}
\hline \multirow[t]{2}{*}{ Characteristics of respondents } & \multicolumn{2}{|c|}{ Control } & \multicolumn{2}{|c|}{ Case } \\
\hline & $\mathrm{n}$ & $\%$ & $\mathrm{n}$ & $\%$ \\
\hline \multicolumn{5}{|l|}{ Last education } \\
\hline No school & 0 & 0 & 2 & 2 \\
\hline Primary school & 6 & 6 & 7 & 7 \\
\hline Junior high school & 15 & 15 & 25 & 25 \\
\hline High school & 46 & 46 & 36 & 36 \\
\hline College & 33 & 33 & 30 & 30 \\
\hline \multicolumn{5}{|l|}{ Profession } \\
\hline Work & 34 & 34 & 46 & 46 \\
\hline Does not work & 66 & 66 & 54 & 54 \\
\hline \multicolumn{5}{|l|}{ Marital status } \\
\hline Not married & 0 & 0 & 1 & 1 \\
\hline Married & 93 & 93 & 79 & 79 \\
\hline Widow & 7 & 7 & 20 & 20 \\
\hline \multicolumn{5}{|l|}{ Previous cancer history } \\
\hline There is & 0 & 0 & 2 & 2 \\
\hline Nothing & 100 & 100 & 98 & 98 \\
\hline \multicolumn{5}{|l|}{ Previous history of breast disease } \\
\hline There is & 6 & 6 & 7 & 7 \\
\hline Nothing & 94 & 94 & 93 & 937 \\
\hline
\end{tabular}

with risk categories is $58 \%$ in the case group and $43 \%$ in the control group. The frequency distribution of respondents based on the age at birth of their first child with a risk category was $29 \%$ in the case group and $6 \%$ in the control group. The frequency distribution of respondents based on parity with risk categories was $32 \%$ in the case group and $18 \%$ in the control group. The frequency distribution of respondents based on breastfeeding history with risk categories was $34 \%$ in the case group and $11 \%$ in the control group. Meanwhile, the frequency distribution of respondents based on menopausal age was $14 \%$ in the case group and $10 \%$ in the control group.

Table 2: Univariate analysis results

\begin{tabular}{|c|c|c|c|c|}
\hline \multirow[t]{2}{*}{ Variable/category } & \multicolumn{2}{|c|}{ Control } & \multicolumn{2}{|c|}{ Case } \\
\hline & $\mathrm{n}$ & $\%$ & $\mathrm{n}$ & $\%$ \\
\hline \multicolumn{5}{|l|}{ Menarche's age } \\
\hline It's risky & 58 & 58 & 43 & 43 \\
\hline No risk & 42 & 42 & 57 & 57 \\
\hline Total & 100 & 100 & 100 & 100 \\
\hline \multicolumn{5}{|c|}{ Childbirth age of first child } \\
\hline It's risky & 29 & 29 & 6 & 6 \\
\hline No risk & 71 & 71 & 94 & 94 \\
\hline Total & 100 & 100 & 100 & 100 \\
\hline \multicolumn{5}{|l|}{ Parity } \\
\hline It's risky & 32 & 32 & 18 & 18 \\
\hline No risk & 68 & 68 & 82 & 82 \\
\hline Total & 100 & 100 & 100 & 100 \\
\hline \multicolumn{5}{|c|}{ Breastfeeding history } \\
\hline It's risky & 34 & 34 & 11 & 11 \\
\hline No risk & 66 & 66 & 89 & 89 \\
\hline Total & 100 & 100 & 100 & 100 \\
\hline \multicolumn{5}{|l|}{ Menopausal age } \\
\hline It's risky & 14 & 14 & 10 & 10 \\
\hline No risk & 86 & 86 & 90 & 90 \\
\hline Total & 100 & 100 & 100 & 100 \\
\hline
\end{tabular}

The results of research related to breast cancer risk factors in terms of female reproductive factors (bivariate analysis results) are shown in Table 3. Where, in Table 3 it is known that the age of menarche $(p=0.034)$, age at first birth $(p=0.000)$, parity $(p=0.022)$, and history of breastfeeding $(p=0.000)$ were associated with breast cancer incidence. Meanwhile, the age of menopause $(p=0.384)$ did not correlate with the incidence of breast cancer. In the variable age of menarche, an OR value of 1.83 (Cl: 1.045-3.207) was obtained, which means that women with menarche age in the risk category $(<12$ years) were 1.83 times more likely to develop breast cancer than women whose menarche age was not at risk ( $\geq 12$ years). In
Table 3: Results of bivariate analysis

\begin{tabular}{|c|c|c|c|c|c|c|}
\hline \multirow{2}{*}{ Variable/category } & \multicolumn{2}{|c|}{ Control } & \multicolumn{2}{|c|}{ Case } & \multirow[t]{2}{*}{$p$-value } & \multirow{2}{*}{$\begin{array}{l}\text { OR } \\
(95 \% \mathrm{Cl})\end{array}$} \\
\hline & $\mathrm{n}$ & $\%$ & $\mathrm{n}$ & $\%$ & & \\
\hline \multicolumn{7}{|l|}{ Menarche's age } \\
\hline It's risky & 58 & 58 & 43 & 43 & \multirow[t]{3}{*}{0.034} & \multirow{3}{*}{$\begin{array}{l}1.83 \\
(1.045-3.207)\end{array}$} \\
\hline No risk & 42 & 42 & 57 & 57 & & \\
\hline Total & 100 & 100 & 100 & 100 & & \\
\hline \multicolumn{7}{|c|}{ Childbirth age of first child } \\
\hline It's risky & 29 & 29 & 6 & 6 & \multirow[t]{3}{*}{0.000} & \multirow{3}{*}{$\begin{array}{l}6.39 \\
(2.521-16.243)\end{array}$} \\
\hline No risk & 71 & 71 & 94 & 94 & & \\
\hline Total & 100 & 100 & 100 & 100 & & \\
\hline \multicolumn{7}{|l|}{ Parity } \\
\hline It's risky & 32 & 32 & 18 & 18 & \multirow[t]{3}{*}{0.022} & \multirow{3}{*}{$\begin{array}{l}2.14 \\
(1.107-4.152)\end{array}$} \\
\hline No risk & 68 & 68 & 82 & 82 & & \\
\hline Total & 100 & 100 & 100 & 100 & & \\
\hline \multicolumn{7}{|c|}{ Breastfeeding history } \\
\hline It's risky & 34 & 34 & 11 & 11 & \multirow[t]{3}{*}{0.000} & \multirow{3}{*}{$\begin{array}{l}4.16 \\
(1.967-8.830)\end{array}$} \\
\hline No risk & 66 & 66 & 89 & 89 & & \\
\hline Total & 100 & 100 & 100 & 100 & & \\
\hline \multicolumn{7}{|l|}{ Menopausal age } \\
\hline It's risky & 14 & 14 & 10 & 10 & \multirow[t]{3}{*}{0.384} & \multirow{3}{*}{$\begin{array}{l}1.26 \\
(0.618-3.175)\end{array}$} \\
\hline No risk & 86 & 86 & 90 & 90 & & \\
\hline Total & 100 & 100 & 100 & 100 & & \\
\hline
\end{tabular}

the variable age at first birth, an OR value of $6.39(\mathrm{Cl}$ : 2.521-16.243) was obtained, which means that women with the age of giving birth to their first child in the risk category (> 30 years) have a 6.39 times tendency to develop breast cancer than women who have had their first child age at birth of their first child in the category of no risk ( $\leq 30$ years). Whereas in the parity variable, the OR value was 2.14 (Cl: 1.107-4.152), which means that women with parity in the risk category (have never given birth/have given birth only once) is 2.14 times more likely to develop breast cancer than women whose parity is in the non-parity category risky (Have given birth more than once). Meanwhile, in the variable of breastfeeding history, the OR value was 4.16 (Cl: 1.967-8.830), which means that women with a history of breastfeeding in the risk category (never breastfeeding/breastfeeding $<12$ months) had a 4.16 times tendency to develop breast cancer than women whose breastfeeding history is in the no-risk category (breastfeeding $\geq 12$ months).

The results of the multivariate analysis (Table 4) show that the reproductive factors most significantly associated with the incidence of breast cancer were the age at birth of the first child $(p=$ $0.001)$ and breastfeeding history $(p=0.001)$. The most dominant factor-related was the age at birth of the first child, although the $p$-value was the same as the $p$-value for the history of breastfeeding; however, the $\operatorname{Exp}(B)$ value for the age at birth of the first child was greater (5.11) than the Exp value (B) for the history of breastfeeding (3.66).

Table 4: Results of multivariate analysis

\begin{tabular}{llll}
\hline Variable & $\mathrm{p}$ & $\operatorname{Exp}(\mathrm{B})$ & $\mathrm{Cl}(95 \%)$ \\
\hline Childbirth age of first child & 0.001 & 5.11 & $1.90-13.71$ \\
Breastfeeding history & 0.001 & 3.66 & $1.64-8.16$ \\
\hline
\end{tabular}

\section{Discussion}

Based on studies conducted, it is known that the age of menarche is a risk factor for breast cancer, where there is a relationship between the age of menarche and 
the incidence of breast cancer. This result is in line with several previous studies; Anggorowati (2013) about the risk factors for women's breast cancer that there is a relationship between the age of menarche and breast cancer with $\rho=0.000$ and an OR of $6.66(95 \%$ Cl: 2.84-15.65) [8]. According to Ardiana et al. (2013) regarding the analysis of reproductive risk factors related to the incidence of breast cancer in women, there is a relationship between the age of menarche and breast cancer with $\rho=0.001$ and an OR of $5.76(95 \%$ Cl: 2.08-15.97) [9]. According to research by Dewi and Hendrati (2015) on breast cancer risk analysis based on a history of hormonal contraceptive use and age of menarche, there is a relationship between menarche and the incidence of breast cancer with $p=0.031$ and OR 3.49 (95\% Cl: 1.11-10.91) [10]. The results of this study are also following the theory that the earlier the age of menarche, the greater the risk of suffering from breast cancer. The risk of developing breast cancer is 2-4 times greater in women who experience menarche before age 12 years. Women who experience early menarche will have longer exposure to estrogen, which is known to increase the risk of developing breast cancer [5].

The age at giving birth to the first child in this study is known to have a relationship with the incidence of breast cancer. This research is in line with research by Sepandi et al. in the journal Breast Cancer Risk Factors in Women Participating in a Breast Screening Program: A Study on 11,850 Iranian Females which states that the age of giving birth to the first child shows a relationship with the risk of breast cancer. Women with first birth experience above 35 years, a higher risk of breast cancer [11]. The results of this study are also in line with Anggorowati (2013) research on risk factors for breast cancer in women that there is a relationship between age at first pregnancy and breast cancer with $\rho=0.000$ and OR 4.99 (Cl: 1.90-13.87) [8]. The results of this study are also consistent with the theory that the older you have your first child, the greater your risk of developing breast cancer. This also has to do with the breastfeeding process. Women who are late in giving birth to their first child will also be late in the breastfeeding phase. When breastfeeding, the hormone estrogen in the female body will decrease and turn into lactation hormone [12]. The hormone estrogen is the culprit of breast cancer, so it would be better if a woman produces lactation hormone before the age of 30 . In another study, it was found that the first gestational age had a greater impact on the risk of breast cancer than the subsequent gestational age [5].

Parity is also a risk factor for breast cancer. In the results of this study, parity has a relationship with the incidence of breast cancer. This study is in line with research by Almeida et al. in the journal Reproductive Risk Factors Differ Among Breast Cancer Patients and Controls in a Public Hospital of Paraiba, Northeast Brazil, which states that parity also shows a significant effect on the incidence of breast cancer. Women who do not have children (nulliparous) 2662 have a higher risk of developing breast cancer than multiparous women who have children $\geq, 2$ people. This can be seen from the results of his study with an OR of 2.662 (95\% Cl: 1.173-6.041; $p=0.019)$ [13]. This result is also consistent with the results of research by Priyatin et al. (2013) which showed that nulliparous parity (OR = 4.353; $95 \% \mathrm{Cl}=1.463-8.898$ ) was at risk of increasing the incidence of breast cancer [14].

Nulliparity can increase the risk of developing breast cancer due to longer exposure to the hormone estrogen. High levels of the hormone estrogen during a woman's reproductive period, especially if not accompanied by hormonal changes (in pregnancy and breastfeeding) increase the chances of growing cells that are genetically damaged and cause cancer [15]. Nulliparous women have a 4.0 times greater risk of developing breast cancer than multiparous women [8], [15]. Nulliparous women have a higher risk because these women have never breastfed. Women who breastfeed the levels of the hormones estrogen and progesterone will remain low during breastfeeding so that it can affect the proliferation of tissues including breast tissue and can protect against breast cancer [9], [16], [17].

Breastfeeding history in the results of this study also has a relationship with the incidence of breast cancer, so that the history of breastfeeding is a risk factor for breast cancer. This research is in line with research by Almeida et al. in the journal Reproductive Risk Factors Differ Among Breast Cancer Patients and Controls in a Public Hospital of Paraiba, Northeast Brazil (2015) which states that breastfeeding has a significant protective effect on the risk of breast cancer. Women who breastfed for more than 24 months showed an increase in OR 0.308 (95\% Cl: 0.12-0.847) against women who were not breastfeeding ( $p=0.022)$ [13]. The results of this study are also in line with Anggorowati's 2013 research on risk factors for women's breast cancer that there is a relationship between a history of breastfeeding and breast cancer in women with a $\rho=0.00$ and an OR of 5.49 (95\% Cl: 2.05-14.74) [8]. According to research by Ardiana et al. (2013) on the analysis of reproductive risk factors associated with the incidence of breast cancer in women, there is a relationship between a history of breastfeeding and breast cancer in women [9].

According to Putera (2015), the risk of breast cancer will decrease if women breastfeed frequently and for a long time or 2 years. Breastfeeding can affect the level of estrogen in a woman's body to be lower. The hormone estrogen in women is the main ingredient in breast cancer. Breastfeeding can reduce estrogen levels, therefore a woman's risk of developing breast cancer will decrease every time a woman becomes pregnant and breastfeeds [9], [12], [18]. Breastfeeding 
will suppress the menstrual cycle; breastfeeding can help eliminate toxins in the breast. Breastfeeding can cause changes in breast cells that make female cells more resistant to cancer-related cell mutations [18], [19], [20].

\section{Conclusion}

The results of this study indicate that age at menarche, age at first birth, parity, and history of breastfeeding are risk factors for breast cancer in women. However, the age of menopause in this study was not a risk factor for breast cancer in women because the results of the study did not have a relationship between menopause age and the incidence of breast cancer. Based on the results of this study, women must get married immediately at the ideal age and not delay having children, so that they can immediately enter the breastfeeding phase.

\section{References}

1. Globocan (IARC). Estimated Breast Cancer Mortality Worldwide in 2012. Geneva, Switzerland: Globocan (IARC); 2015.

2. World Health Organization. Breast Cancer Estimated Incidence, Mortality and Prevalence Worldwide. Geneva: World Health Organization; 2018. http://globocan.iarc.fr/old/FactSheets/ cancers/breast-new.asp PMid:25114560

3. World Health Organization. Breast Cancer Estimated Incidence, Mortality and Prevalence Worldwide. Geneva: World Health Organization; 2012. http://globocan.iarc.fr/old/FactSheets/ cancers/breast-new.asp

4. Kemenkes RI. Info Datin Bulan Peduli Kanker Payudara. Indonesia: Kemenkes RI; 2016.

5. Rasjidi, Pencegahan Kanker Pada Wanita, Sagung-Seto, Jakarta; 2010.

6. Nurrachmah E. Breast cancer and treatment of the bio-psychospiritual aspects of clients participating in support groups. $J$ Indonesian Nurs. 2016;2(6):1-2. https://doi.org/10.7454/jki. v2i6.90
7. Shadine M. Penyakit Wanita Pencegahan, Deteksi Dini, dan Pengobatannya. Yogyakarta: Citra Pustaka; 2012.

8. Anggorowati L. Breast cancer risk factors in kudus hospital. $J$ Public Health. 2013;8(2):121-6.

9. Ardiana A, Negara HW, Sutisna M. Analysis of reproductive risk factors associated with breast cancer incidence in women. Health J. 2013;1(2):106. https://doi.org/10.24198/jkp.v1n2.6

10. Dewi GA, Hendrati LY. Breast cancer risk analysis based on history of hormonal contraception use and age of menarche. Periodic J Epidemiol. 2015;3(1):12-23.

11. Sepandi M, Akrami M, Tabatabaee H. Breast cancer risk factors in women participating in a breast screening program: A study on 11 850 Iranian females. Asian Pac J Cancer Prev. 2014;15:8499-502. https://doi.org/10.7314/apjcp.2014.15.19.8499 PMid:25339054

12. Rizema P. Buku Lengkap Kanker Payudara. Itanov Cetakan I: Yogyakarta; 2015.

13. de Almeida GS, Amanda LA, Araujo GM, Weller M. Reproductive risk factors differ among breast cancer patients and controls in a public hospital of Paraiba, Northeast Brazil. Asian Pac J Cancer Prev. 2015;16(7):2959-65. https://doi.org/10.7314/ apjcp.2015.16.7.2959

PMid:25854389

14. Priyatin C, Ulfiana E, Sumarni S. Risk factors affecting the incidence of breast cancer at RSUP DR. Kariadi Semarang. J Obstet. 2013;2(5):9-19. https://doi.org/10.31983/jrk.v6i1.2085

15. Budiningsih S, Ohno Y, Prihartono J, Ramli M, Wakai K, Cornain $\mathrm{S}$, et al. Epidemiological analysis of risk factors for breast cancer in Indonesian females. Med $\mathrm{J}$ Indones. 2015:4(3):163. https://doi.org/10.13181/mji.v4i3.913

16. Indrati R. Faktor Risiko Yang Berpengaruh Terhadap Ca Payudara Wanita di RS DR. Kariadi Semarang, Undip-Tesis; 2015.

17. Putri F, Hafiza S. Risk factors affecting the incidence of breast cancer. J Public Health. 2013;2(5):115-8.

18. Chlebowski RT, Manson JE, Anderson GL, Cauley JA, Aragaki AK, Stefanick ML, et al. Estrogen plus progestin and breast cancer incidence and mortality in the Women's health initiative observational study. J Natl Cancer Inst. 2013;105(8):526-35. https://doi.org/10.1093/jnci/djt043 PMid:23543779

19. Anggraini L. Breast cancer risk factors in women. J Public Health. 2014;8(2):102-8.

20. Balekouzou A, Yin P, Pamatika CM, Bekolo CE, Nambei SW, Djeintote $\mathrm{M}$, et al. Reproductive risk factors associated with breast cancer in women in Bangui: A case-control study. BMC Womens Health. 2017;17(1):14. https://doi.org/10.1186/ s12905-017-0368-0

PMid:28264686 